\title{
Development and Characterization of Novel Composites from Soy Bean Protein
}

\author{
Ajaya Kumar Behera* and Chirasmayee Mohanty \\ Department of Chemistry, Utkal University, India
}

*Corresponding author: Department of Chemistry, Utkal University, Bhubaneswar, Odisha 751004, India, Tel: 8280098214; Email: ajayabehera@gmail.com

\section{Research Article \\ Volume 3 Issue 1}

Received Date: January 28, 2019

Published Date: March 18, 2019

DOI: $10.23880 /$ macij-16000132

\section{Abstract}

Soy based nano-biocomposites were prepared using different percentages of montmorillonite (MMT), and Cloisite 20A nanoclays with soy resin by solution casting process. Protein content was calculated using Lowry's method. X-ray diffraction (XRD) and transmission electron microscopy (TEM) analysis were carried out to explore the intercalation/exfoliation nature of clay inside soy. Scanning electron microscopy (SEM) analysis of nanoclay reinforced soy composite suggests distribution of nanoclay inside the matrix domain. From soil burial degradation analysis, it was found that developed composites are completely degradable in nature. The novel nanoclay soy resin formulation can be employed as matrix for fiber reinforced composite fabrication as well as developed nano-biocomposites can be utilized as low strength packaging materials by replacing synthetic polymer and that based composites.

Key words: Biopolymer; Nanocomposites; Biodegradability; Bio-resin; Soy resin

Abbreviations: MMT: Montmorillonite, XRD: X-ray Diffraction, TEM: Transmission Electron Microscopy, SEM: Scanning Electron Microscopy, SPC: Soy Protein Concentrate, SPI: Soy Protein Isolate, MSF: Modified Soy composite Films, SF: Soy composite Film, CA: Crosslinking Agent, CSF: Cloisite modified Soy composite Film.

\section{Introduction}

Soy bean is the world's foremost oilseed source and the primary source of protein. It comprises around $45 \%$ proteins and $18 \%$ oil. The research on soy protein resin, extracted from soybean is now creating top spot in the field of green composite. During the process of soy oil extraction from soy bean, soy flour is obtained as a secondary product and it can be purified to obtain soy protein concentrate (SPC) and soy protein isolate (SPI). Soy protein is commercially available in three grades (i) soy flour (containing $50 \%$ of soy protein), (ii) SPC (containing $70 \%$ of soy protein) and (iii) SPI (containing $90 \%$ of soy protein). SPC and SPI are preferably chosen by many researchers over soy oil for the preparation of natural fiber reinforced composites due to presence of higher percentage of protein $[1,2]$.

Henry Ford pioneered the use of soy protein for plastics and natural fibers in automotive sector. Soy protein offers several advantages over synthetic polymers, as soy protein extraction process is environment friendly and these proteins can form ductile and viscous polymers that can be used as resins. The most advantageous nature is of it being low cost of the raw materials (soy seeds) and 


\section{Medicinal \& Analytical Chemistry International Journal}

abundancy. The growing environmental thermoplastic pollution problem of petroleum product can be iradicated by considering soy protein as its alternative [3]. Huang and Netravali have reported about the use of soy protein and soy flour and their modified structure as matrix with natural fibers for development of completely biodegradable and sustainable composites [4].

The soy resin can reduce environment pollution as it is completely degradable in nature, but poor mechanical properties, poor processability, and high hydrophilicity which limit their application in fabrication of natural fiber-reinforced composite [5]. For wide application and property enhancement of bio resins, nanoparticles play significant role. When nanoparticles are evenly dispersed in bio-resins by small volume fraction, nanocomposites turn out to improved physical and mechanical properties. Among nanoparticles, naturally occurring nanoclay [Montmorillonite (MMT)] and organically modified nanoclay (Cloisite 15A, 20A, and 30B) have already been reported as good reinforcement for bio-resins [6]. Both MMT and organically modified nanoclay have structures of stacked platelets, where the thickness of each platelet is around one nanometer. The other dimensions of nanoclays are in the range of several hundred nanometers. This high aspect ratio of nanoclay particularly improves the mechanical properties of its corresponding composites [7].

Chen, et al. investigated MMT reinforced SPI composite and reported improvement in tensile strength from 8.77 $\mathrm{MPa}$ to $15.43 \mathrm{MPa}$ for 0 to $16 \mathrm{wt} \%$ of MMT loading [8]. Young's modulus of composite also enhanced with increase in nanoclay content due to the formation of strong electrostatic and hydrogen bonding between the soy protein and clay layers. Nayak, et al. also developed MMT modified SPI composite using $0-15 \mathrm{wt} \%$ of MMT and reported an increase in tensile strength and modulus value with increase in nanoclay loading [9]. Huang and Netravali, reported about the SPC resin modified with $40 \%$ phytagel and 7\% MMT and claimed an improvement of tensile modulus $(2.1 \mathrm{GPa})$ and tensile strength $(72.5 \mathrm{MPa})$ which are more than that of the unmodified composite. They also reported about the improvement in moisture resistance, storage modulus and thermal stability of modified SPC resin over unmodified one [10]. Shabeer, et al. fabricated soy based epoxy/MMT clay nanocomposite and found that nanoclay improved the tensile modulus and tensile strength by $625 \%$ and $340 \%$, respectively than the unmodified SPC composite due to exfoliation of nanoclay [11]. Lee \& Kim studied the properties of MMT reinforced SPI composite and found that $12 \mathrm{wt} \%$ of nanoclay loaded composite showed optimal condition [12]. Kumar, et al. fabricated Cloisite 20A reinforced soy composite and reported that $5 \mathrm{wt} \%$ clay loaded nanobiocomposite films demonstrated better mechanical, dynamic mechanical, and water barrier properties as compared to that of MMT reinforced composite [13]. Iman and Maji prepared biocomposites using MMT, soy flour and jute fabric. They reported that increment in nanoclay from 0 to $5 \mathrm{wt} \%$ in composite improved the thermal stability, flame retardancy, dimensional stability, and most importantly the mechanical properties. Rhim developed different sets of soy protein composites using MMT, Cloisite 20A, and Cloisite 30B, respectively. According to him, Cloisite 20A (5 wt\%) reinforced composite showed better mechanical and water barrier properties among others [14].

The practical challenge in fabricating nanoclay reinforced composite is the dispersion of nanoclay in polymer. There are three important methods used as solution casting, melt blending and in-situ polymerization method for dispersion of nanoclay in polymer matrix. Shear mixing and ultrasonic mixing are two methods of implementation followed largely. In this work, nanobiocomposites were developed using soy resin and nanoclay by solution casting process and the properties of soy composites due to MMT and Cloisite $20 \mathrm{~A}$ were reported. Soy proteins have a number of free hydroxyl groups and it is expected that these functional groups can interact with nanoclay layers and other additives forming secondary bonding. Hence, the use of crosslinked soy resin can improve the physical and mechanical properties of the composites. Based on these concepts, nanoclay modified soy resins were prepared, characterized, and reported.

\section{Experimental}

\section{Materials}

Montmorillonite (MMT), and Cloisite 20A were obtained from Southern Clay Products (Gonzales, TX). Glyoxal (Merck, India), Glycerol (Merck, India), Ammonium hydroxide $\left(\mathrm{NH}_{4} \mathrm{OH}\right)$ (Merck, India) and Acetone (Merck, India) were procured from local market. Soy bean was procured from the local market.

\section{Extraction of soymilk}

Soy seeds were washed properly and soaked in distilled water (1:4 $\mathrm{w} / \mathrm{v}$ ratios) for $4 \mathrm{~h}$. Water soaked soy seeds were crushed in a mixer grinder (using excess water) to get soy paste. Soy milk was extracted from soy 


\section{Medicinal \& Analytical Chemistry International Journal}

paste by squeezing and filtering through nylon cloth. About $1500 \mathrm{ml}$ of soy milk was obtained from $500 \mathrm{~g}$ of soy seeds. Then soy milk was made alkaline by adding ammonium hydroxide $\left(\mathrm{NH}_{4} \mathrm{OH}\right)(5 \mathrm{ml} / 100 \mathrm{ml}$ soy milk) in order to stabilize from bacterial degradation. The $\mathrm{pH}$ of soy milk was measured by using a digital $\mathrm{pH}$ meter $\mathrm{PH}$ 5652 (Electronic Corporation of India Ltd.). The pH of freshly prepared soy milk was found around $7.0( \pm 0.5)$ and for the preservation of soy milk, $\mathrm{pH}$ was maintained at $9.0-10.0$ by adding ammonia hydroxide. Solid content of soy milk was determined by taking $10 \mathrm{ml}$ of soy milk in a dry $10 \mathrm{~cm}$ diameter petridish and weighed [15]. The solid content of soy milk was found to be $20 \%$. Basing on solid content, resin formulation was done using glyoxal as crosslinking agent and glycerol as plasticizer.

\section{Preparation of soy resin, nanoclay modified soy resin and their composite}

Different weight percentages of glyoxal $(1,5,10,15$, and $20 \mathrm{wt} \%$ ) (w/w, solid content of soy milk) along with $10 \mathrm{wt} \%$ of glycerol (w/w, solid content of soy milk) were added to required amount of soy milk and stirred for 30 min to prepare soy resin. Soy resin with various formulations was poured on a $10 \mathrm{~cm}$ diameter flat glass petridish and dried at $60^{\circ} \mathrm{C}$ for $1 \mathrm{~h}$ in a vacuum oven for drying the excess water, and then it was kept in a thermal chamber at $110^{\circ} \mathrm{C}$ for $5 \mathrm{~min}$. Then dark brown soy composite film (SF) was formed. Soy composite films are coded as SF1- SF5 with respect to wt\% of glyoxal. These films were kept in open air for $30 \mathrm{~min}$ to absorb some moisture, which helps for easy peeling.

Different weight percentages of MMT $(1,3,5,7$, and 10 $\mathrm{wt} \%, \mathrm{w} / \mathrm{w}$ of solid resin $\mathrm{wt}$ ) were dispersed in acetone $(25 \mathrm{ml}$ ) by stirring for $30 \mathrm{~min}$ in separate batches (using magnetic stirrer). Each batch of dispersed nanoclay was added to soy milk and stirred well. Then $10 \mathrm{wt} \%$ glyoxal (w/w of resin) and $10 \mathrm{wt} \%$ of glycerol (w/w of resin) were added to it with continuous stirring for another 30 min to prepare MMT modified soy resins. In order to prepare a clay modified composite film about $50 \mathrm{ml}$ of modified soy resin was poured on a flat glass petridish of diameter $10 \mathrm{~cm}$ (water was removed), and kept in a thermal chamber at $110^{\circ} \mathrm{C}$ for $5 \mathrm{~min}$. Then the petridish was taken out and kept in open air for $1 \mathrm{~h}$ to acquire some moisture (for easy peeling). Fabricated MMT modified soy composite films (MSF) are coded as MSF1- MSF5, respectively with respect to MMT content [16]. Different weight percentages of Cloisite $20 \mathrm{~A}(1,3,5,7$, and $10 \mathrm{wt} \%$, $\mathrm{w} / \mathrm{w}$ of solid resin wt) were dispersed following the above process to prepare cloisite modified soy composite film (CSF). These are coded as CSF1-CSF5 with respect to Cloisite 20A content. All MSF and CSF formulations are reported in Table 1.

\begin{tabular}{|c|c|c|c|c|c|}
\hline $\begin{array}{l}\text { Modified soy resin } \\
\text { film }\end{array}$ & Soy milk (wt\%) & Glyoxal (wt\%) & Glycerol (wt\%) & Nanoclay (wt\%) & Type of nanoclay \\
\hline SF3 & 80 & 10 & 10 & 0 & \multirow{6}{*}{ MMT } \\
\hline MSF1 & 79 & 10 & 10 & 1 & \\
\hline MSF2 & 77 & 10 & 10 & 3 & \\
\hline MSF3 & 75 & 10 & 10 & 5 & \\
\hline MSF4 & 73 & 10 & 10 & 7 & \\
\hline MSF5 & 70 & 10 & 10 & 10 & \\
\hline CSF1 & 79 & 10 & 10 & 1 & \multirow{5}{*}{ Cloisite 20A } \\
\hline CSF2 & 77 & 10 & 10 & 3 & \\
\hline CSF3 & 75 & 10 & 10 & 5 & \\
\hline CSF4 & 73 & 10 & 10 & 7 & \\
\hline CSF5 & 70 & 10 & 10 & 10 & \\
\hline
\end{tabular}

Table 1: Formulation of MMT modified soy composite film (MSF) and Cloisite 20A modified soy composite film (CSF).

\section{Estimation of Carbohydrate and Protein Content in Soy}

The anthrone-sulphuric acid method is an example of determining the concentration of the total carbohydrate in a sample. The soy sample was mixed with sulfuric acid and anthrone reagent, and then boiled until the reaction is completed. The solution was then allowed to cool and its absorbance was measured at $620 \mathrm{~nm}$. There is a linear relationship between the absorbance and the amount of carbohydrate present in the original soy sample. This method determines both reducing and non-reducing carbohydrates because of the presence of the strongly oxidizing sulfuric acid [17]. 


\section{Medicinal \& Analytical Chemistry International Journal}

Lowry's method of protein estimation was used to estimate protein in soy sample. At first soy samples were treated with cupric ions under alkaline conditions. Those facilities the chemical combination of cupric ions with peptide bonds of aromatic protein residues (FolinCiocalteu reaction). In the first step of the reaction, protein binds to copper in alkaline medium and produces $\mathrm{Cu}^{++}$. In the second step, $\mathrm{Cu}^{++}$catalyses oxidation of aromatic amino acid by reducing phosphomolybdicphosphotungstic components in the Folin-Ciocalteu reagent to develop blue color, which was measured by absorbance at $750 \mathrm{~nm}$ [18]. The protein and carbohydrate content in soy milk are shown in Table 2.

\begin{tabular}{|c|c|c|}
\hline Sample & $\begin{array}{c}\text { Protein } \\
\text { (mg/g) }\end{array}$ & $\begin{array}{c}\text { Carbohydrate } \\
\text { (mg/g) }\end{array}$ \\
\hline Soy bean with hull & $305-452$ & $400-450$ \\
\hline $\begin{array}{c}\text { Soy bean without } \\
\text { hull }\end{array}$ & $294-422$ & $380-416$ \\
\hline Soy milk & $300-350$ & $290-320$ \\
\hline
\end{tabular}

Table 2: Protein and carbohydrate content in soy.

\section{Characterizations}

\section{Analysis of Tensile Properties}

Tensile properties of SF, MSF, and CSF were characterized in accordance with ASTM D638-03 with a cross head speed of $5 \mathrm{~mm} / \mathrm{min}$ and gauge length of 50 $\mathrm{mm}$ using universal testing machine (HOUNSFIELD H10KS UTM). Six specimens of each sample were tested and average value is reported.

\section{Wide Angle X-Ray Diffraction (WAXD) Analysis}

WAXD analysis of optimized MSF and CSF were performed using a X-ray diffractometer (WAXD, ULTIMAIII, Rigaku, Japan) with nickel filtered $\mathrm{Cu}-\mathrm{K} \alpha$ radiation $(\lambda=$ $0.154 \mathrm{~nm}$ ) operated at $40 \mathrm{kV}$ and $100 \mathrm{~mA}$, at a scanning rate of $1^{\circ} / \mathrm{min}$. The interlayer (d) spacing of nanoclay was calculated for specimen using following equation:

$$
n \lambda=2 d \sin \theta \ldots \ldots \text { (1) }
$$

Where, $\mathrm{n}$ is the order of reflection, $\lambda$ is the wavelength of radiation, $\theta$ is the angle of diffraction, and ' $d$ ' is the interlamellar spacing.

\section{TEM Analysis}

Transmission electron microscopy (TEM) analyses for bulk morphology study of optimized CSF and MSF were investigated using a HRTEM (JEM-2100, JEOL, Japan) instrument with an acceleration voltage of $100 \mathrm{kV}$ and high vacuum. Powder samples of optimized CSF and MSF were dispersed in acetone and a drop of solution was taken on carbon coated copper foil for analysis.

\section{Soil Burial Degradation Study}

Soil burial test for biodegradation of MSF and CSF samples was conducted as per BIS1623-92 standard. Test samples were pre-weighed $\left(W_{0}\right)$ and noted. The compost for soil burial tests was prepared by mixing garden soil, sand and manure in 2:1:1 ratio (by weight). Specimen to soil weight ratio was maintained at 1:100 (w/w) and the samples were buried under compost within a glass jar. The moisture of soil bed was kept as $30 \%$. The sample size was maintained as $15 \mathrm{~cm} \times 5 \mathrm{~cm}$. The glass jar was covered and incubated at $32{ }^{\circ} \mathrm{C}$ for 60 days. The samples were removed at regular time periods $(7,15,30,45$ and 60 days), washed with distilled water and dried at $105^{\circ} \mathrm{C}$ in an oven for $6 \mathrm{~h}$, weighed $\left(W_{1}\right)$ and weight loss percentage of composites was calculated by using following equation.

$$
\text { Weight loss }(\%)=100 \times \frac{W_{0}-W_{1}}{W_{0}}
$$

\section{Results and Discussion}

\section{Tensile Strength Measurement of SF}

The results of the tensile strength of glyoxal crosslinked soy resin films (SF) are shown in Figure 1. Soy composite film (SF3) prepared with $10 \mathrm{wt} \%$ glyoxal showed the highest tensile strength of $0.97 \mathrm{MPa}$, which might be due to better cross linking between soy protein and glyoxal. Soy proteins are composed of a mixture of albumins and globulins. About $90 \%$ of which are storage proteins with globular structure, consisting mainly with legumin (11S globulin) and vicillins (7S globulin) [19]. Globulins are protein fractions in which the subunits are associated through hydrogen bonding. At alkaline $\mathrm{pH}$ (near to 10), globulins dissociate, protein denatures, and interactions with additives are favored due to an optimum unfolding of protein chains. The protein part of soy milk consists of 18 different amino acids such as lysine, glutamine, asparagines, arginine, etc., which have more than one $\mathrm{NH}_{2}$ group. It was found the tensile strength of soy resin film enhanced from $0.72 \mathrm{MPa}$ to 0.96 $\mathrm{MPa}$ for 5 to $15 \mathrm{wt} \%$ of glyoxal addition. The improvement in tensile strength may be a consequence of a good dipole- dipole/hydrogen bonding interaction between the functional groups of soy protein $\left(-\mathrm{NH}_{2}\right.$ and - 
$\mathrm{COOH}$ ) and the glyoxal which consists up two aldehyde linkage helps in cross-linking between them to produce strong primary electrovalent bonds. So, in order to optimize the amount of crosslinking agent (CA) another set of soy resin films was prepared using 6 to $14 \mathrm{wt} \%$ of glyoxal. Addition of excess of CA does not enhance tensile strength of resin film probably due to less number of available sites in protein of soy milk for bonding. Hence, $10 \mathrm{wt} \%$ of glyoxal is considered optimum as CA for resin formulation.
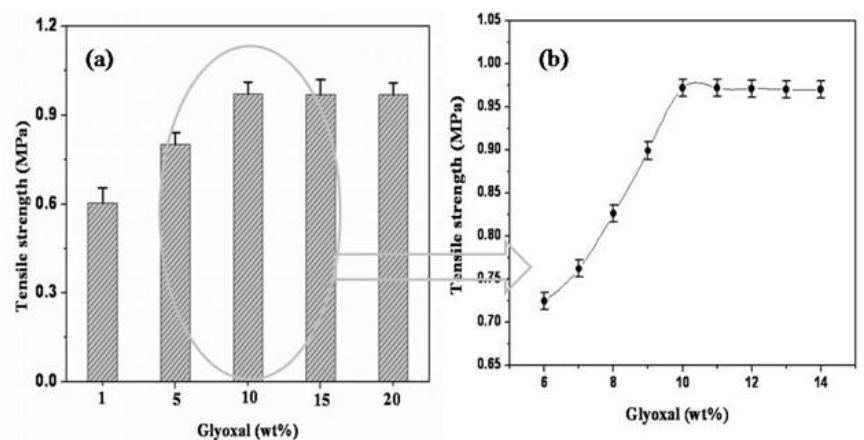

Figure 1: Tensile strength of soy resin film (a) using glyoxal $(1,5,10,15$, and $20 \mathrm{wt} \%)$, and (b) glyoxal $(6,7,8,9,10$, $11,12,13,14$, and $15 \mathrm{wt} \%)$.

\section{Tensile Strength Measurement of MSF and CSF}

The tensile properties of MSF and CSF are reported in Table 3. Soy composite film (SF3) showed the tensile strength of $0.97 \mathrm{MPa}$ and modulus of $82.1 \mathrm{MPa}$ due to cross linking between soy protein and glyoxal [16]. With addition of MMT up to $5 \mathrm{wt} \%$, tensile strength and modulus enhanced up to $1.47 \mathrm{MPa}$ and $178 \mathrm{MPa}$, respectively. CSF3 showed highest strength of $1.91 \mathrm{MPa}$ and modulus of $192.8 \mathrm{MPa}$. Soy protein in soymilk consists of amino acids that contain $\mathrm{NH}_{2}$ group reacted with glyoxal and clay layers to produce strong primary electrovalent bonds. This improvement in properties might be due to interaction of nanoclay with soy resin at the interface. This interaction may be in form of exfoliation or intercalation, both of which help to improve physical and mechanical properties of nano-composite. A probable schematic illustration for interaction of nanoclay with glyoxal crosslinked soy resin is shown in Figure 2.

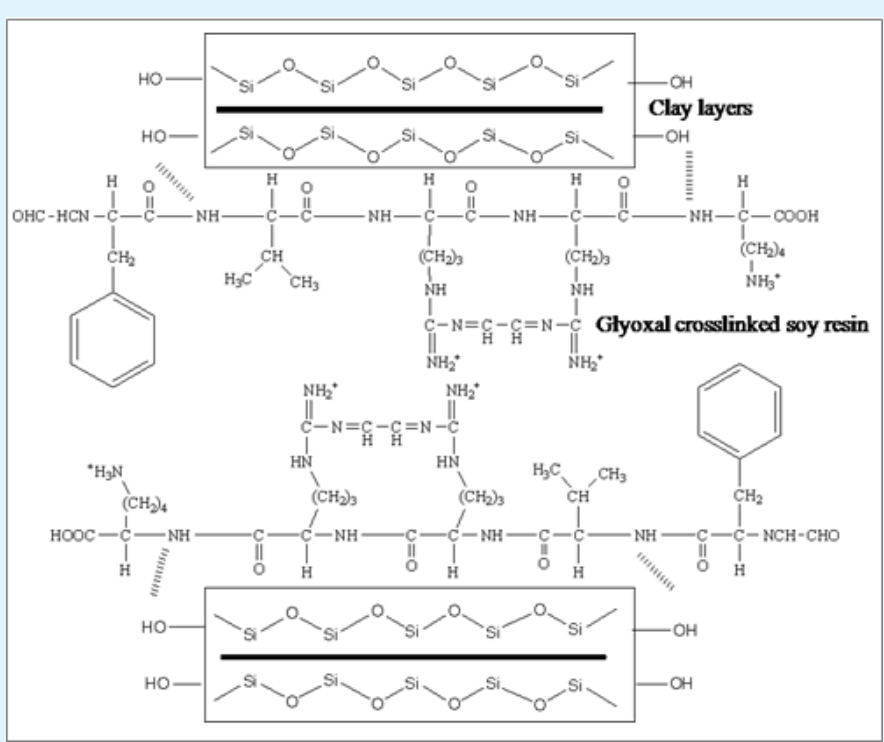

Figure 2: A schematic illustration of probable bonding between silicate layers of nanoclay and glyoxal crosslinked soy protein. 


\section{Medicinal \& Analytical Chemistry International Journal}

\begin{tabular}{|c|c|c|c|c|c|}
\hline \multirow{2}{*}{ Sample } & \multirow{2}{*}{ Clay type } & Clay & aTS $\pm \mathbf{d S D}$ & $\mathbf{b T M} \pm \mathbf{d S D}$ & cEB $\pm \mathbf{d S D}$ \\
\cline { 3 - 6 } & $\mathbf{( \% )}$ & $\mathbf{( M P a )}$ & $\mathbf{( M P a )}$ & $\mathbf{( \% )}$ \\
\hline SF3 & & 0 & $0.97 \pm 0.13$ & $82.1 \pm 10$ & $6.8 \pm 0.11$ \\
\hline MSF1 & & 1 & $1.03 \pm 0.11$ & $125.6 \pm 18$ & $6.4 \pm 0.15$ \\
\hline MSF2 & & 3 & $1.29 \pm 0.17$ & $147.4 \pm 12$ & $6.2 \pm 0.13$ \\
\hline MSF3 & MMT & 5 & $1.47 \pm 0.18$ & $178.0 \pm 16$ & $6.0 \pm 0.19$ \\
\hline MSF4 & & 7 & $1.19 \pm 0.11$ & $142.2 \pm 12$ & $5.6 \pm 0.18$ \\
\hline MSF5 & & 10 & $0.98 \pm 0.10$ & $93.2 \pm 11$ & $5.5 \pm 0.12$ \\
\hline CSF1 & & 1 & $1.28 \pm 0.16$ & $132.2 \pm 10$ & $6.4 \pm 0.11$ \\
\hline CSF2 & & 3 & $1.71 \pm 0.15$ & $165.0 \pm 14$ & $6.2 \pm 0.14$ \\
\hline CSF3 & Cloisite 20A & 5 & $1.91 \pm 0.10$ & $192.8 \pm 12$ & $6.1 \pm 0.18$ \\
\hline CSF4 & & 7 & $1.53 \pm 0.19$ & $159.6 \pm 15$ & $5.8 \pm 0.12$ \\
\hline CSF5 & & 10 & $1.01 \pm 0.11$ & $102.2 \pm 12$ & $5.6 \pm 0.15$ \\
\hline
\end{tabular}

aTS: Tensile strength, bTM: Tensile modulus, cEB: Elongation at break, dSD: Standard deviation

Table 3: Tensile properties of MSF and CSF.

Elongation at break values of MSF and CSF gradually decreased as the clay loading increased from 0 to $10 \mathrm{wt} \%$. The decrease in such properties is due to increase in brittleness of soy matrix. It was found that with inclusion of 3 to 7 wt\% nanoclay, tensile properties of resin increased for both MSF and CSF. Addition of more amount of nanoclay ( $>5 \mathrm{wt} \%$ ) decreased the tensile properties of MSF and CSF. This may be due to the agglomeration of nanoclay within soy matrix [2] which creates defect in the composite for which more amount of adding nanoclay did not improve the mechanical strength. Hence, $5 \mathrm{wt} \%$ of cloisite $20 \mathrm{~A}$ loaded resin film is considered as optimum among all the resin films.

\section{Surface Morphology Analysis of Optimized Resin Film}

The morphology of the soy film, MSF3 and CSF3 sheets were evaluated by observing the surface of sample with scanning electron microscope (SEM). Figure 3 shows the surface morphology of nanoclay modified soy milk. Soy milk contains protein globules of $7 \mathrm{~S}$ and $11 \mathrm{~S}$ globulin. The sample of SF3 surface was found to contain protein globules as soy proteins are prominent constituents in soy milk [20]. In MSF3 (containing 5 wt $\%$ MMT), MMT platelets were well dispersed in the bio-nanocomposite film, which is shown in Figure 3. Different surface morphologies of soy resin films were observed for $5 \mathrm{wt} \%$ cloisite $20 \mathrm{~A}$ loading. The granular shape of soy protein (Figure 3a) got converted into crystallite form (Figure 3c). The SEM views of surfaces of films indicate formation of clustering due to nanoclay interaction with soy resin.

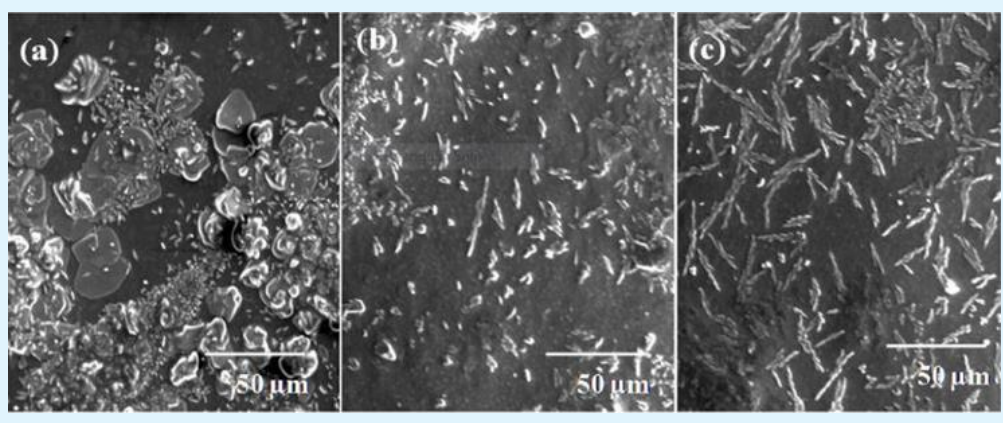

Figure 3: SEM micrographs of (a) SM, (b) MSF3, and (c) CSF3.

\section{XRD analysis of MSF and CSF}

X-ray diffractograms of MSF and CSF with respect to MMT and cloisite 20A are shown in Figure 4. For MMT, a characteristic peak was obtained at around $7.2^{\circ}$ with basal spacing of $1.25 \mathrm{~nm}$. For its corresponding resin film the diffraction peak intensity was reduced with respect to MMT content. For low concentration of nanoclay loading 


\section{Medicinal \& Analytical Chemistry International Journal}

$(1,3,5 \mathrm{wt} \%)$ the diffraction peak shifted towards lower $2 \theta$ region $\left(6.31^{\circ}, 6.34^{\circ}\right.$ and $6.36^{\circ}$, respectively). That indicates formation of intercalated morphology. When high concentration of nanoclay was utilized the diffraction peak vanished (for MSF4 and MSF5) showing exfoliation morphology. For Cloisite 20A, a characteristic peak was obtained at around $3.7^{\circ}$ with $2.4 \mathrm{~nm}$ basal spacing numerically equal to that of the reported value [22]. The absence of peak in CSF indicates that nanoclay platelets were separated during resin formulation.

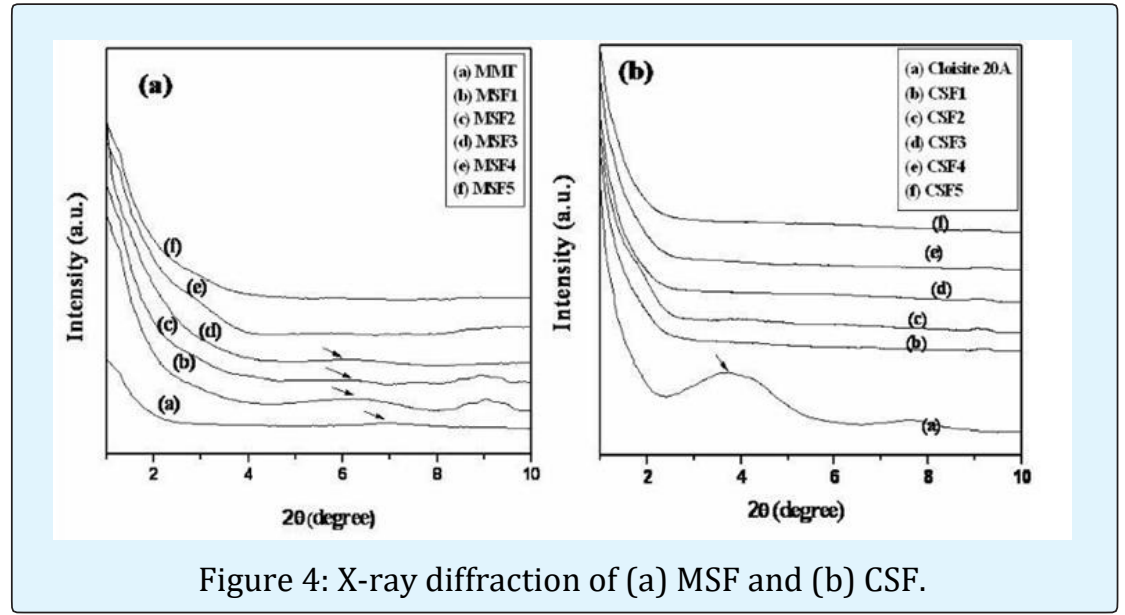

\section{TEM analysis of optimized resin films}

In order to check intercalation and exfoliation between clay and resin XRD analysis of soy resin-MMT (MSF3-MSF5) and soy resin-cloisite 20A (CSF3-CSF5) films are shown in Figure 5. The dark lines in images correspond to MMT platelets and the gap between two adjacent lines is their $\mathrm{d}$ spacing. It shows intercalated structure of nanoclay. When the MMT content increased to $10 \mathrm{wt} \%$ the arrangement of MMT layers changed from intercalated to exfoliated as already discussed in XRD section. The exfoliated morphologies obtained for MSF4 and MSF5 are shown in Figure 5(b) and 5(c), respectively. Cloisite 20A reinforced film, CSF3 showed exfoliated morphology of clay [Figure 5(d)], CSF4 and CSF5 showed exfoliated morphology [21]. Both TEM and XRD analyses of resin film support the formation of intercalated and exfoliated structures of nano-biocomposites.

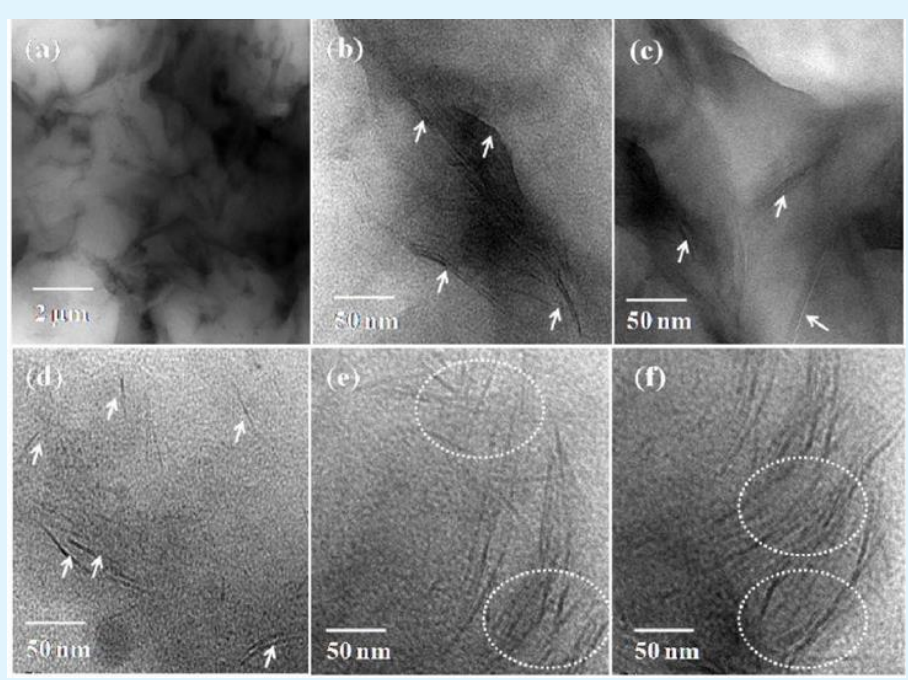

Figure 5: TEM images of (a) intercalated morphology of MSF3, (b) partially exfoliated morphology of MSF4, (c) exfoliated morphology of MSF5, (d) exfoliated morphology of CSF3, (e) exfoliated morphology of CSF4, and (f) exfoliated morphology of CSF5. 


\section{Medicinal \& Analytical Chemistry International Journal}

\section{Soil burial degradation of resin films Weight loss of resin films after biodegradation}

The weight loss after different periods of biodegradation for MSF and CSF sheets are reported in Table 4. Both MSF and CSF sheets are found to completely degraded in composting condition as most of the films lost more than $90 \mathrm{wt} \%$ of initial weight after 60 days of biodegradation. The degraded resin films were handled carefully for further analysis. For all samples initial weight lost was more or less $51 \%$ after 7 days under soil bed. This happened due to loss of water soluble components present in soy matrix. After 60 days of biodegradation it was found that resins are completely destroyed and some are partly collected. That might be due to good degradation nature of soy resin which almost lost its complete mass. It was found that CSF5 lost 93.1\% in weight after 60 days of biodegradation. The less degradation in weight might be due to the presence of silicate layers (nanoclay), which hindered the soil microorganisms attack to break internal bonding.

\begin{tabular}{|c|c|c|c|c|c|}
\hline Sample & $\mathbf{7}$ days & 15 days & 30 days & 45 days & 60 days \\
\hline MSF1 & $51.8 \pm 1.5$ & $70.4 \pm 1.6$ & $81.1 \pm 1.7$ & $88.3 \pm 1.9$ & -- \\
\hline MSF2 & $51.8 \pm 1.7$ & $70.2 \pm 1.8$ & $80.6 \pm 2.1$ & -- & -- \\
\hline MSF3 & $51.6 \pm 1.9$ & $70.3 \pm 1.5$ & $80.3 \pm 2.3$ & $87.4 \pm 1.5$ & $94.6 \pm 1.5$ \\
\hline MSF4 & $51.3 \pm 1.8$ & $70.1 \pm 1.6$ & $80.1 \pm 1.9$ & --- & -- \\
\hline MSF5 & $51.0 \pm 1.6$ & $69.6 \pm 1.9$ & $79.7 \pm 1.8$ & $87.1 \pm 1.6$ & $87.1 \pm 1.6$ \\
\hline CSF1 & $51.4 \pm 1.8$ & $70.1 \pm 1.5$ & $80.4 \pm 1.5$ & -- & -- \\
\hline CSF2 & $51.2 \pm 1.5$ & $69.6 \pm 1.7$ & $79.6 \pm 1.6$ & $86.8 \pm 1.6$ & -- \\
\hline CSF3 & $51.0 \pm 1.4$ & $69.3 \pm 1.5$ & $79.3 \pm 1.9$ & $86.1 \pm 1.8$ & $93.4 \pm 1.5$ \\
\hline CSF4 & $51.1 \pm 1.5$ & $69.0 \pm 1.3$ & $80.1 \pm 1.4$ & -- & -- \\
\hline CSF5 & $50.7 \pm 1.2$ & $68.6 \pm 1.6$ & $78.7 \pm 1.7$ & $85.8 \pm 1.4$ & $93.1 \pm 1.7$ \\
\hline
\end{tabular}

Table 4: Weight loss (\%) of nanoclay loaded soy sheets after different periods of biodegradation.

\section{Conclusion}

Both MMT and cloisite 20A were successfully utilized to develop soy composite by solution casting method. The tensile strength of soy composite film (CSF3) was improved by $97 \%$ as compared to that of virgin soy film for inclusion of $5 \mathrm{wt} \%$ Cloisite 20A. This enhancement in properties was obtained due to formation of exfoliated morphology in resin validated by XRD and TEM analyses. Biodegradation analysis revealed that developed resins lost more than $90 \%$ of its original weight after 60 days under soil bed. Both the resin compositions (CSF and MSF) were used as matrix with natural and synthetic fibre to develop nano- biocomposites. These composites can be used for making low strength packaging, decorating, household materials, etc.

\section{References}

1. Ma W, Qi B, Sami R, Jiang L, Li Y, et al. (2018) Conformational and functional properties of soybean proteins produced by extrusion-hydrolysis approach. Int J of Anal Chem.

2. Behera AK, Adhikari B (2015) Jute Reinforced NanoBiocomposite for Structural and Industrial Applications. Appl Sc and Adv Mat Int 2: 11-15.
3. Aouada FA, Mattoso LC, Longo E (2011) New strategies in the preparation of exfoliated thermoplastic starch-montmorillonite nanocomposites. Ind Crops \& Prod 34(3): 1502-1508.

4. Adekunle K, Patzelt C, Kalantar A, Skrifvars M (2012) Mechanical and viscoelastic properties of soybean oil thermoset reinforced with jute fabric and carded lyocell fiber. J Appl Polym Sc 122(5): 2855-2863.

5. Behera AK (2015) "Lignocellulosic fiber reinforced soy composites: An alternative to plastic product" Ajaya Kumar Behera. Appl Sc \& Adv Mat Int 1: 160164.

6. Ashori A, Nourbakhsh A (2009) Effects of Nanoclay as a reinforcement filler on the physical and mechanical properties of wood-based composite. J Comp Mater 43(18): 1869-1875.

7. Iman M, Maji TK (2013) Effect of crosslinker and nanoclay on jute fabric reinforced soy flour green composite. J Appl Polym Sc 127(5): 3987-3996.

8. Chen P, Zhang L (2006) Interaction and properties of highly exfoliated soy protein- montmorillonite nanocomposites. Biomacromol 7(6): 1700-1706. 


\section{Medicinal \& Analytical Chemistry International Journal}

9. Nayak P, Sahoo S, Behera A, Nanda P, Nayak P, et al. (2011) Synthesis and characterization of soy protein isolate/MMT nanocomposite film for the control release of the drug ofloxacin. World J of Nano Sc \& Eng 1(2): 27-36.

10. Huang X, Netravali A (2007) Characterization of flax fiber reinforced soy protein resin based green composites modified with nano-clay particles. Compos Sc \& Technol 67(10): 2005-2014.

11. Shabeer A, Chandrasekhara K, Schuman T (2007) Synthesis and Characterization of Soy-based Nanocomposites. J of Comp Mat 41(15): 1825-1849.

12. Lee JE, Kim KM (2010) Characteristics of soy protein isolate-montmorillonite composite films. Journal of Applied Polymer Science 118(4): 2257-2263.

13. Kumar R, Choudhary V, Mishra S, Varma IK (2008) Banana fiber-reinforced biodegradable soy protein composites. Front of Chem in China 3(3): 243-250.

14. Rhim JW (2009) Effect of clay type and concentration on optical, tensile and water vapor barrier properties of soy protein isolate/clay nanocomposite films. J of Korea Soc of Packag Sc \& Technol 15(3): 99-104.

15. Behera AK, Avancha S, Basak RK, Sen R, Adhikari B (2012) Fabrication and characterization of biodegradable jute reinforced soy based green composites. Carbohyd Polym 88(1): 329-335.
16. Behera AK, Avancha S, Sen R, Adhikari B (2013) Development and characterization of nanoclay modified soy resin based jute composite as an ecofriendly/green product. Polym Plast Technol \& Eng 52(8): 833-840.

17. Leyva A, Quintana A, Sanchez M, Rodriguez EN, Cremata J, et al. (2008) Rapid and sensitive anthronesulfuric acid assay in microplate format to quantify carbohydrate in biopharmaceutical products: Method development and validation. Biologicals 36(2): 134141.

18. Lowry OH, Rosebrough NJ, Farr AL, Randall RJ (1951) Protein measurement with the folin phenol reagent. J of Bio Chem 193(1): 265-275.

19. Esmaili I, Sadeghi HM, Akbari V (2018) Effect of buffer additives on solubilization and refolding of reteplase inclusion bodies. Res Pharm Sci 13(5): 413421.

20. Behera AK, Avancha S, Manna S, Sen R, Adhikari B (2014) Effect of nanoclay on physico-mechanical properties and microbial degradation of jute reinforced soymilk based nano- biocomposites. Polym Eng \& Sc 54(2): 345-354.

21. Nigrawal A, Prajapati SC, Chand N (2012) Mechanical and thermal properties of nano-cellulose obtained from sisal fiber reinforced polyvinyl alcohol (PVA) biocomposites. J Sc Res \& Rev 1: 20-25. 